\title{
\#USGS @CZM
}

\begin{tabular}{l}
$\begin{array}{l}\text { U.S. Department of the Interior } \\
\text { U.S. Geological Survey }\end{array}$ Scientific Investigations Map 3286 \\
\hline
\end{tabular}

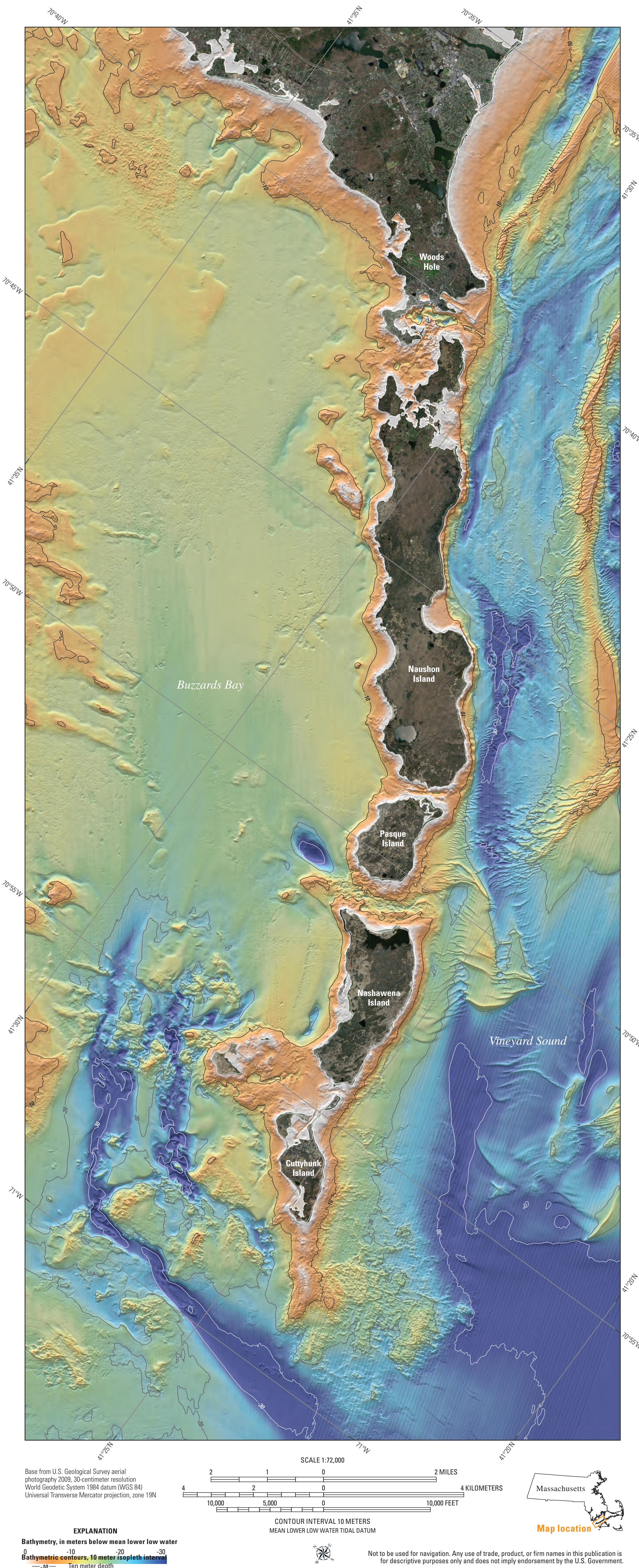

Bathymetry of the Waters Surrounding the Elizabeth Islands, Massachusetts By
Elizabeth A. Pendleton, Brian D. Andrews, Seth D. Ackerman, and David C. Twichell
2014

Discussion

The Elizabeth Islands in Massachusetts that separate
Vineyard Sound from Buzzards Bay are the remnants of a moraine (unconsolidated glacial sediment deposited at an ic
sheet margin: Oldale and O' $0^{\prime}$ Hara 1984) The most recent glacial ice retreat in this region occurred between 25,000 an 20,000 years ago, and the subsequent rise in sea level that
followed deglaciation caused differences in the seafloor
haracter between Buzzards Bay and Vinevard Sound. The character between Buzzards Bay and Vineyard Sound. Th
relatively rough seafloor of Vineyard Sound reflects

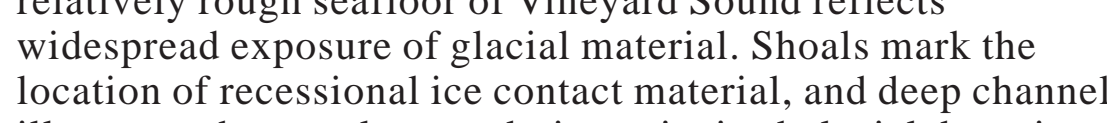
Following ice retreat from the Elizabeth Islands, a glacial th formed across the mouth of Buzzards Bay, when the lake Sea level rise began to inundate Vineyard Sound and
the bay Buzzards Bay about 8,000 years ago and continueve to modify
the modern seafloor (Robb and Oldale, 1977). Fine-grained marine and estuarine sediments were deposited in the partially
protected setting of Buzzards Bay. These deposits up to 10 meters in thickness, buried the high-relief glacial landscape and created the genereally smooth modert seafloor. In contrast
the Vineyard Sound of today experiences strong tidal currents
which largely prevernt the deposition of fine-grained which largely prevent the deposition of fine-grained materiad
and constantly rework the glacial sand and gravel within shools. The seafloor of the sound largely reflects the contours
of the ancient glaciated landscape that existed before sea lev

The bathymetric data used to create the hillsh ded risef thage of the seafloor were collected by the U.S. Geodogicical Coastal Zone Management and supplemented with National Oceanic and Atmospheric Administrtation hydrographic survey
data. The map shows the detailed bathymetry of Buzzards Bay deepest are The aerial photographye for the Elizabeth 5 slands and
Massachusetts mainland were obtained from the Massachusetts Data collected during this statewide cooperatives been released in a series of USGS open-file reports. These publications ath intormation regarding geologic mapping in
Massachusetts can be obtained from the Coastal and Marine Geollogy Program's Web site
(http://woodshole.er.usgs.gov/project-pages/coastal_mass).

References Cited

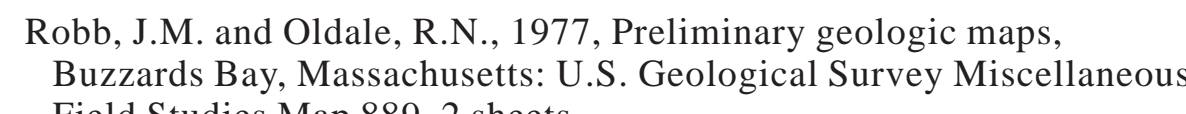
Oldale, R.N., and O'Hara, C.J., 1984, Glaciotectonic origin of the
Massachusetts coastal end moraines and a fluctuating late Wisconsinan ice margin: Geological Society of America Bulletring
v. 95 , no. 1, p. $61-74$. 